\title{
Assessment of the impact of acute inflammation on the anti-cancer responses in a mouse model
}

\author{
Sohaila M Galal", Mohamed L Salem, Zeinab A Ibrahim \\ From Society for Immunotherapy of Cancer 28th Annual Meeting \\ National Harbor, MD, USA. 8-10 November 2013
}

\section{Background}

Inflammation is a vital process induced by microbial infection or tissue injury. The main function of inflammation is to resolve the infection or repair the damage and return the body to a state of homeostasis. Acute inflammation can induce signals that result in two main functions: 1) initiation of an inflammatory cascade that helps limits the infection and 2) activation of the immune response. In this study we determined the impact of the nature and magnitude of acute inflammation on the host anti-tumor activity against Ehrlich Ascites cancer cell (EAC) line as a model system which forms either peritoneal ascites upon intraperitoneal injection.

\section{Design}

Different inflammatory signals, including agonists for tolllike receptor (TLR) 2 (zymosan) and TLR3 agonist (poly (I:C) or its clinical grade Hiltonol ${ }^{\circledR}$ ), complete Freund's adjuvant (CFA), and incomplete Freunds Adjuvant (IFA), and BCG from Bacillus calmatte (TLR9 agonist) were used to induce acute inflammation 1 day after i.p. challenge with EAC.

\section{Results}

We found that Hiltonol ${ }^{\circledR}$, poly (I:C), IFA, CFA, and BCG induced inflammatory cells associated with anti-tumor activity that resulted in significant decrease in the tumor growth measured by the total number of tumor cells after 7 days of tumor challenge. Of interest, among the test TLR agonists both poly(I:C) and Hiltonol ${ }^{\circledR}$ (TLR3 agonist) showed the highest anti-tumor effects.

\section{Conclusions}

Provision of the proper inflammatory signal with optimally defined magnitude and duration during cancer growth will

Zoology, Faculty of Science, Tanta, Egypt induce inflammatory cells with potent anti-tumor responses leading to significant decreases in tumor growth.

Published: 7 November 2013

\section{doi:10.1186/2051-1426-1-S1-P267}

Cite this article as: Galal et al:: Assessment of the impact of acute inflammation on the anti-cancer responses in a mouse model. Journal for ImmunoTherapy of Cancer 2013 1(Suppl 1):P267.
Submit your next manuscript to BioMed Central and take full advantage of:

- Convenient online submission

- Thorough peer review

- No space constraints or color figure charges

- Immediate publication on acceptance

- Inclusion in PubMed, CAS, Scopus and Google Scholar

- Research which is freely available for redistribution
() Biomed Central 